\title{
GENETICS IN ENDOCRINOLOGY Glucocorticoid resistance syndrome
}

\author{
Géraldine Vitellius ${ }^{1,2}$ and Marc Lombes ${ }^{1,3}$ \\ 'INSERM UMR_S U1185, Fac Med Paris-Sud, Univ. Paris-Sud, Université Paris Saclay, Le Kremlin Bicêtre, France, \\ ${ }^{2}$ Service d'Endocrinologie-Diabète-Nutrition, Hôpital Robert Debré, CHU Reims, Reims, France, and '3Service \\ d'Endocrinologie et des Maladies de la Reproduction, Hôpitaux Universitaires Paris Sud, AH-HP, CHU Bicêtre, Le \\ Kremlin Bicêtre, France
}

Correspondence should be addressed to M Lombes

Email

marc.lombes@u-psud.fr

\begin{abstract}
Glucocorticoids (GC) such as cortisol regulate multiple physiological functions, notably those involved in development, metabolism, inflammatory processes and stress, and exert their effects upon binding to the glucocorticoid receptor (GR, encoded by NR3C1 gene in humans). GC signaling follows several consecutive steps leading to target gene transactivation, including ligand binding, nuclear translocation of ligand-activated GR complexes, DNA binding, and recruitment of functional transcriptional machinery. Generalized glucocorticoid resistance syndrome, due to GR loss-of-function mutations, may be related to the impairment of one of the GC signaling steps. To date, 31 NR3C1 loss-of-function mutations have been reported in patients presenting with various clinical signs such as hypertension, adrenal hyperplasia, hirsutism or metabolic disorders associated with biological hypercortisolism but without Cushing syndrome signs and no negative regulatory feedback loop on the hypothalamic-pituitary-adrenal axis. Functional characterization of GR loss-of-function mutations often demonstrates GR haploinsufficiency and a decrease of GR target gene induction in relevant cell types. The main signs at presentation are very variable from resistant hypertension, bilateral adrenal hyperplasia likely related to increased ACTH levels but not exclusively, hirsutism to isolated renin-angiotensin-aldosterone system abnormalities in a context of $11 \beta \mathrm{HSD} 2$ deficiency. Some mutated GR patients are obese or overweight together with a healthier metabolic profile that remains to be further explored in future studies. Deciphering the molecular mechanisms altered by GR mutations should enhance our knowledge on GR signaling and ultimately facilitate management of GC-resistant patients. This review also focuses on the criteria facilitating identification of novel NR3C1 mutations in selected patients.
\end{abstract}

\section{Invited Author's profile}

Dr Marc Lombes is presently the Head of Research, INSERM Unit 1185, Université Paris Saclay, Paris, France. Dr Lombes, is a leader in the field of Mineralocorticoid Receptor (MR) signaling, andhis group is internationally recognized as one of the active teams in the field of steroid receptor biology. The group studies the mechanism of action of steroid hormones by analyzing the expression and function of MR and its implication in human pathophysiology, including newborns. The group has also characterized several mutations in the glucocorticoid receptor in patients.

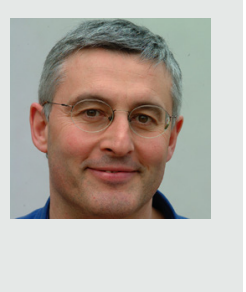

Published by Bioscientifica Ltd. 


\section{Introduction}

\section{Glucocorticoid (GC) resistance, an old syndrome recently revisited}

The first patient presenting with glucocorticoid resistance syndrome was described in 1976 (1), in whom high blood pressure was incidentally found in association with hypokalemia and high urinary free cortisol (UFC) reaching 30-40 times the normal reference values (2). Since this princeps publication, 31 glucocorticoid receptor (GR) lossof-function mutations have been identified in patients presenting with very variable clinical and biological signs. In this review, we will briefly introduce the GR and the GC mechanism of action and discuss the GC resistance syndrome. Finally, we will focus on the new findings concerning the molecular mechanisms behind some of the clinical signs observed in mutated GR patients. These novel results definitely challenge the current view concerning the pathophysiology of glucocorticoid resistance syndrome and suggest alternative management approaches for such patients.

\section{Glucocorticoid receptor and glucocorticoid mechanism of action}

Glucocorticoid hormones regulate various biological functions involved in development (cardiac, liver and pulmonary development $(3,4))$, metabolism (hyperglycemia and insulin resistance), adipose tissue (adipogenesis and obesity (5)), inflammatory processes (decrease of inflammatory process (6)) and stress. Cortisol excess, such as observed in Cushing's syndrome patients, is responsible notably for skin atrophy, proximal myopathy, truncal and visceral obesity or osteoporosis but also for hyperglycemia, hypertension or neuropsychological disturbances (7). Cortisol release is under the control of hypothalamic corticotropin-releasing hormone (CRH), which stimulates corticotrope cells of the anterior pituitary, responsible for pro-opiomelanocortin (POMC) transcription and adrenocorticotropic hormone (ACTH) release. ACTH may bind MC2R, a 7-transmembrane $G$ protein-coupled receptor, expressed in all zones of the adrenal cortex and activates the cAMP (adenosine 3'5'-cyclic monophosphate) pathway, responsible for production and release of cortisol from zona fasciculata of adrenal cortex. Cortisol exerts a negative feedback on hypothalamic-pituitary axis (HPA) on CRH and ACTH (8).

GC, which are primarily cortisol in humans, act mainly by binding to and activating the human GR (hGR), an intracellular receptor protein acting as a ligand-activated transcription factor. hGR is encoded by the NR3C1 gene (MIM\#138040), located on chromosome 5 in humans and belongs to the nuclear receptor superfamily. NR3C1, consisting of at least ten exons, from 1 to 9, encodes a 777-amino acid hGR protein that may exist under multiple protein isoforms of the hGR protein generated by alternative splicing: hGR $\alpha, h G R \beta, h G R \gamma, h G R-A$ and hGR-P. Additionally eight alternative initiation start sites into hGR $\alpha$ have been previously described $(9,10)$. These mechanisms generate distinct GR protein variants with distinct transactivation properties. As illustrated in Fig. 1, exon 2 encodes the N-Terminal Domain (NTD; 1-419 aa), with a sequence coding for the transactivation domain involved in transcriptional activation of GR target genes. Exons 3 to 4 encode the DNA-binding domain (DBD; 420-487 aa), whose two zinc fingers playing a key role in recognition of specific glucocorticoid response elements (GREs) on regulatory sequences of DNA target genes and are also involved in GR dimerization. Exon 5 encodes the hinge region, between the DBD and the ligand-binding domain (LBD), whose role remains unclear but some lysine residues undergo acetylation by the heterodimer of circadian transcription factors CLOCK/BMAL1 (11). Exons 5 to 9 encode the LBD (488-777 aa), composed of $11 \alpha$-helices and $4 \beta$-strands, responsible for ligand binding and GR transactivation.

The main GR signaling pathway is the genomic pathway which leads to DNA-GR interaction and subsequent activation or repression of the downstream transcription. GC can bind cytoplasmic GR under its heterooligomeric, multiprotein chaperon complex via H1 helix interaction (12). GR conformational changes occurring after ligand binding lead to the repositioning of the H12 helix while the ligand-receptor complex is translocated into the nucleus. Inside the nuclear compartment, GR can homodimerize and interact with GREs or half-sites or degenerate GRE on DNA target genes, promoting their transcription (13). The classical GRE is a DNA target sequence composed of a palindromic sequence of 15 nucleotides 5'-AGAACAnnnTGTTCT-3' but, as mentioned earlier, GRs can also bind hemi-GRE or degenerate GREs (14). GRE recruitment is cell-specific following a given agonist treatment, but may differ in vitro since GRs have been reported to be recruited to various GREs (14). It has been also shown that GRs can also heterodimerize with the closely related receptor, the mineralocorticoid receptor (MR) (15). In addition, GR may also interact with other transcription factors via functional tethering to regulate gene expression (16) or by non-genomic interaction via membrane glucocorticoid receptor (17). 


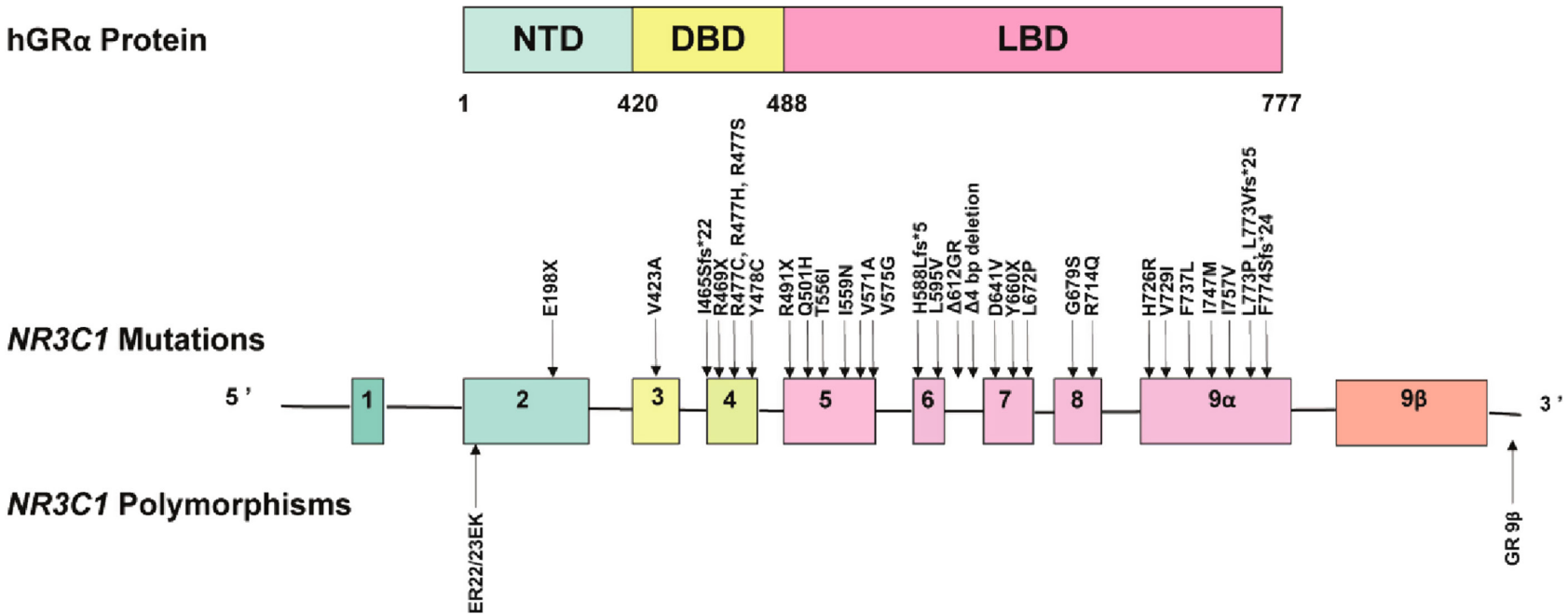

\section{Figure 1}

GR loss-of-function mutations and polymorphisms of NR3C1 (up to June 2019). Schematic representation of the GR $\alpha$ protein functional domains NTD, DBD and LBD and location of GR loss-of-function mutations and polymorphisms on NR3C1 gene. Three main functional domains are described in GR protein: The N-Terminal domain (NTD; 1-419 aa) encoded by exon 2, the DNAbinding domain (DBD; 420-487 aa) encoded by exon 3 and 4 and the ligand-binding domain (LBD; 488-777 aa) encoded by exons 5-9. Schematic illustration of NR3C1 gene with the 10 exons. Upper panel: Thirty-one GR loss-of-function mutations have been identified to date in the NR3C1 gene in 33 patients. Note that two mutations (G679S and R714Q) were reported in two non-related patients while two other mutations (E198X and R714Q) were identified in the same patient. Lower panel: Location of two NR3C1 polymorphisms associated with GC resistance: the first polymorphism, located in the exon 2 of the NR3C1 gene, ER22/23EK (rs6189, rs6190) polymorphism corresponds to two linked changes in codons 22 and 23, GGA.GAG to GAA.AAG, leading to one amino acid from ER to EK. The second polymorphism GR-9ק (rs6198 or A3669G) is a A $\rightarrow$ G change, located in the 3' UTR end of the exon $9 \beta$. rs, single nucleotide polymorphism; NTD, N-terminal domain, DBD, DNA-binding domain; LBD, ligand-binding domain.

\section{Glucocorticoid resistance}

Definition

Generalized glucocorticoid resistance syndrome has a tremendously heterogenous and very broad clinical spectrum. It has been defined by an absence of overt Cushing's syndrome signs (no skin weakness, muscle atrophy, or osteoporosis (7)) associated with biological hypercortisolism consisting of high urinary free cortisol (UFC) and an absence of negative feedback loop of cortisol on HPA, defined as 8-AM cortisol level >50 nmol/L after overnight 1 mg DXM suppression test(DST). Glucocorticoid resistance syndrome may also be discovered as partial and cell specific rather than generalized glucocorticoid resistance syndrome, associated with the cell resistance to DXM-induced apoptosis in a context of hemopathy and leukemia or more frequently in the context of a persistent disease despite a full dose of GC therapy classified as DXMtreatment resistance; these will not be discussed in this review. Generalized glucocorticoid resistance is mainly described in the context of GR loss-of-function mutations in the NR3C1 gene, except the rare cases in which no such GR loss-of-function mutations were identified (18).

Some NR3C1 polymorphisms are also linked to glucocorticoid resistance syndrome, notably ER22/23EK (rs6189 and rs6190) and GR-9 $\beta$ (rs6198) which were shown to be responsible for decreased GR transactivation (19, 20), but the involvement of these NR3C1 polymorphisms in GC resistance syndrome seems to be inconsistent and varies according to different studies. They appear to be associated with healthier metabolic profile $(21,22)$.

\section{NR3C1 mutations}

Thirty-one GR loss-of-function mutations have been associated with a glucocorticoid resistance syndrome (MIM\#615962) $(13,23,24,25)$, while 33 index cases have been reported $(13,23,24)$. These mutations are summarized in Table 1 and depicted in Fig. 1. Two GR mutations (G679S $(26,27)$ and R714Q $(28,29)$ ) were identified in two non-related patients, while E198X and R714Q mutations $(25,28)$ were identified in the same 


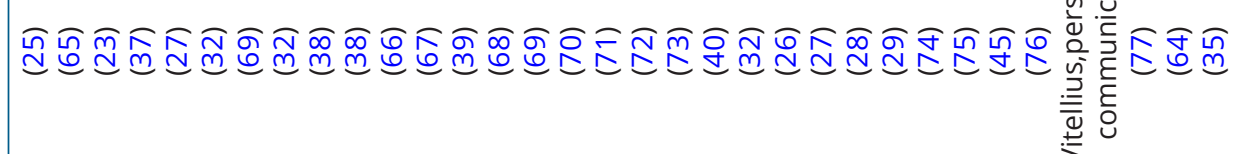

گ

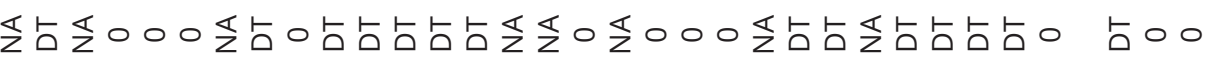

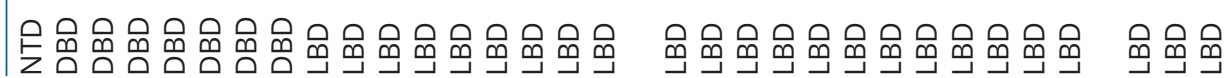

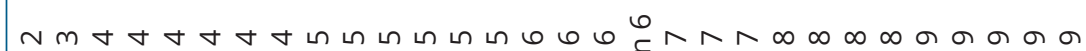

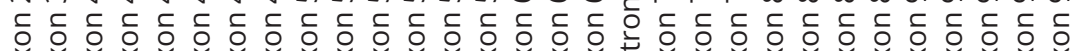

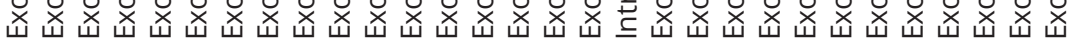

ब $\sigma$

ᄃำ ㄷำ

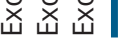

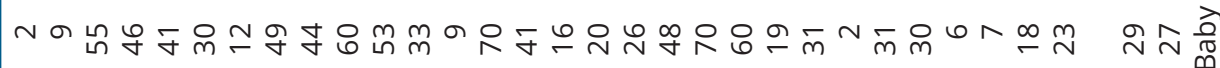

:

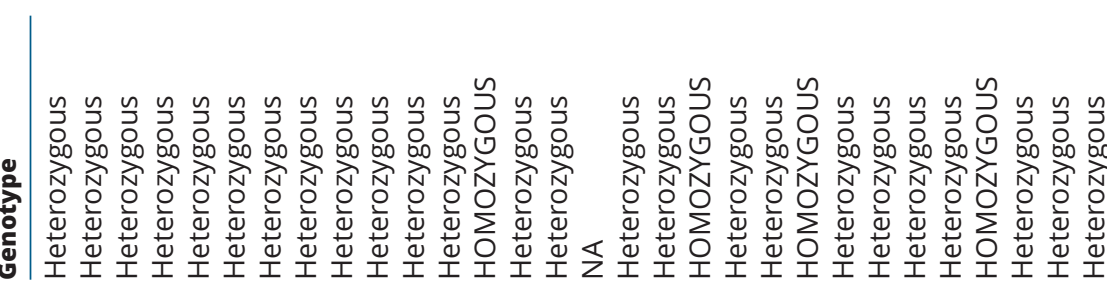

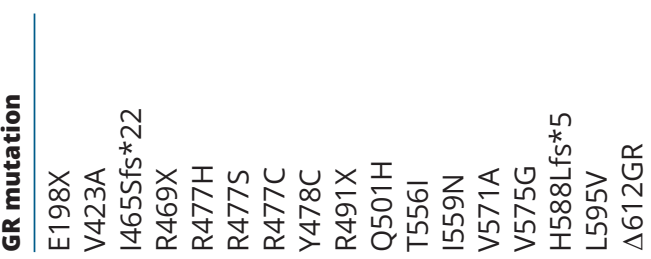

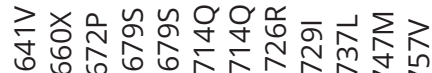

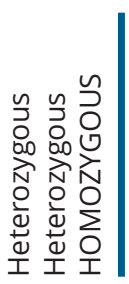

|

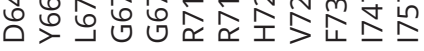
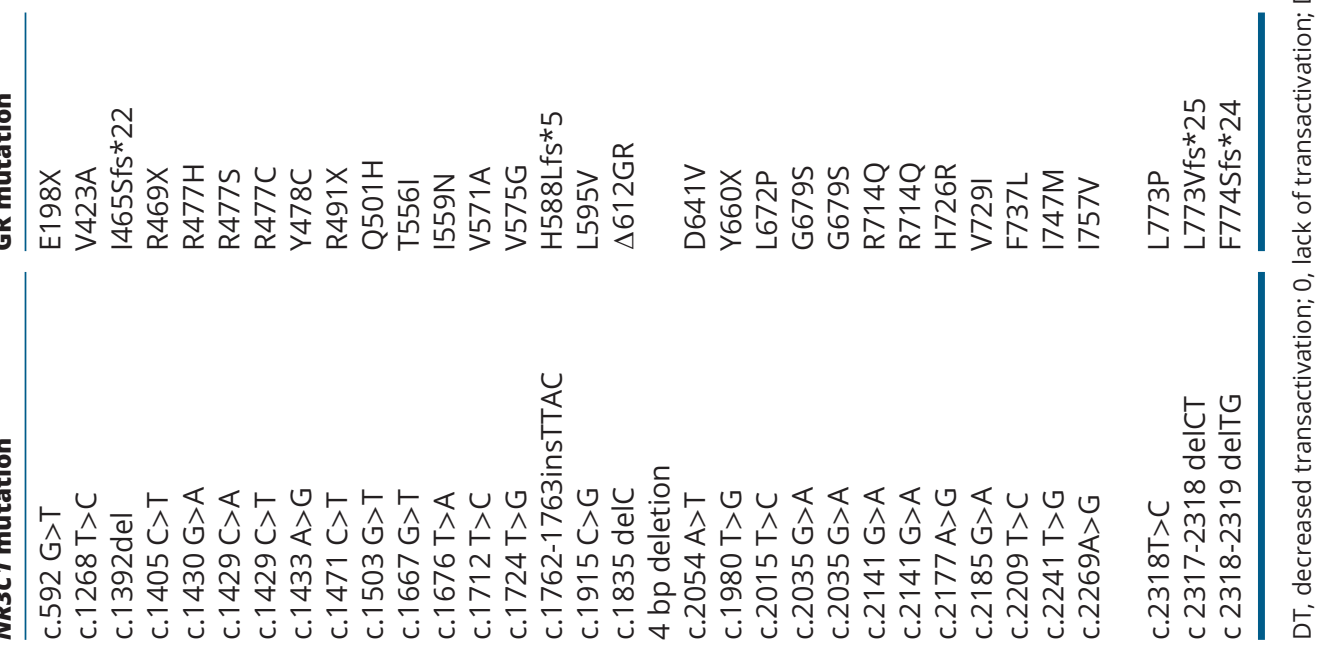
Table 2 Major clinical signs in mutated GR patients.

\begin{tabular}{ll}
\hline Clinical signs in GR loss-of-function mutations & \\
\hline Adrenal hyperplasia & $81.3 \%$ \\
Hirsutism in women & $76.5 \%$ \\
High blood pressure & $48.3 \%$ \\
Overweight obesity & $42.1 \%$ \\
\hline
\end{tabular}

patient, R714Q was a de novo mutation $(25,28)$. Among the 31 GR loss-of-function mutations, 23 were missense mutations, 4 were frameshift mutations. Four nonsense (stop) mutations have been reported so far. Unfortunately, in few cases these mutations have not been functionally characterized to ascertain the deleterious consequences of the identified mutation nor have other family members been examined to validate the phenotype-genotype relationship, by searching for a co-segregation of the affected allele and clinical or biological signs when possible. One stop mutation was located in the NTD (E198X) of the GR, seven mutations were in the DBD (V423A, I465fs ${ }^{\star} 22$, R469X, R477H, R477C, R477S, Y478C), while the others were located in the LBD of GR. The vast majority (27/33 i.e. $82 \%$ ) of the GR mutations were heterozygous, while the five others were homozygous. The age of symptom onset among these patients varied from birth to adulthood, probably in relation with the severity of the clinical presentation of the glucocorticoid resistance syndrome that is itself highly variable, ranging from neonatal hypoglycemia to premature death. Table 2 summarizes some phenotypic presentations of such mutated GR patients. There is no gender specificity: since 19 patients were female (58\%) and 14 males (42\%). As expected, none of GC-resistant patients had overt Cushing's syndrome signs. In sharp contrast, all patients had biological hypercortisolism even though three patients had normal UFC (UFC in the normal value range), only one had normal plasma cortisol concentrations after DST but nine patients had normal ACTH levels when tested. DST seems to be the most relevant screening test to diagnose glucocorticoid resistance syndrome, as recommended by several Endocrine Societies (30, 31). Only one patient had normal HPA axis except midnight cortisol level above 50 $\mathrm{nmol} / \mathrm{L}$. Although certainly interesting, monitoring the 24-h cortisol cycle is very rarely reported.

The functional characterization of the GR variants from these patients generally used transient transfections in in vitro models $(32,33)$. Each step of GR signaling pathway may be evaluated by different techniques. In general, site-directed mutagenesis is used to generate the GR mutation under study in an appropriate expression vector. These are then transiently co-transfected with various GRE-driven reporter luciferase constructs (MMTVLuc, GRE2-Luc, etc.) into cell lines expressing low levels of endogenous wild-type GR such as HEK293T or COS-7 cells. Dose-dependent curves of GC agonists can then be established for different GR mutants, facilitating direct comparison of their 50\% maximal transactivation capacity (EC50 values). Using appropriate and validated antibodies, Western blot analysis can determine the level of GR mutant protein expression as well as examine the existence of truncated variants. These analyses may also be exploited to investigate the potential proteasome-dependent degradation of GR mutants such as L672P following treatment with proteasome inhibitors such as MG-132 (30). In addition, immunofluorescence experiments may be used to determine GR subcellular localization following GC exposure. Automated high-throughput microscopy allows quantification of GR fluorescence in distinct subcellular compartments enabling determination of cyto-nuclear indexes and direct comparison of the kinetics of GC-dependent nuclear translocation of the different GR mutants (32). Finally, co-transfection with vectors expressing coregulators can be used to explore the synergistic potential of some coactivators such as SRC2 (33). Some GR mutants are unable to bind DXM and consequently are not able to translocate into the nucleus in response to DXM, such as R469X, R491X, $4612 \mathrm{GR}$, D641V, Y660X, L672P, I757V, L773Vfs*25, F774Sfs*24, while other mutants such as $\mathrm{R} 477 \mathrm{~S}$ and $\mathrm{R} 477 \mathrm{H}$ cannot bind DNA as determined by reporter gene assays and further validated by chromatin immunoprecipitation (ChIP) experiments (32, 34) (Fig. 2). When functional characterization has been performed, GR transactivation was found to be nonexistent for eleven GR mutations, two of which were homozygous in index cases. The first homozygous GR mutation was discovered in an adult male (1), whereas the second homozygous GR mutation was identified in a term-born Caucasian boy on day 1 of life (35). Transcriptional activities of other GR mutations were generally reduced (Fig. 2). Mutations located in the LBD often presented with a defect in the recruitment of a transcriptional coregulatory partner (Table 1 ). Of interest, different authors used patients' cells, either peripheral blood mononuclear leukocytes or fibroblasts after skin biopsy, to explore the functional consequences of GR mutations in very pertinent cell-based systems. These ex vivo models are extremely valuable since they recapitulate the physiological situation given that both wild type and mutated GRs are co-expressed within the same cell in the case of a heterozygous mutation or monoallelic genetic defect. A GR haploinsufficiency was often demonstrated, 


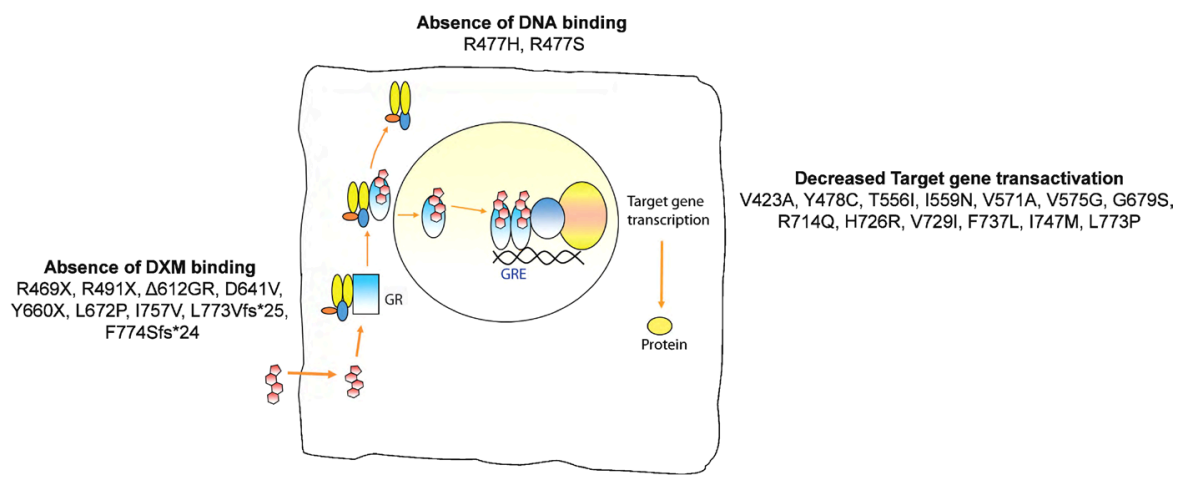

\section{Figure 2}

GC signaling pathway defect associated with GR loss-of-function mutations. Some GR mutants are not able to bind DXM, such as R469X, R491X, $6612 \mathrm{GR}$, D641V, Y660X, L672P, 1757V, L773Vfs*25 and F774Sfs*24 and other GR mutants are incapable of binding DNA as validated by ChIP: R477S and R477H. Transactivation reporter assays explore the whole GR signaling pathway, notably the ability for GR to transactivate a plasmid containing a GRE associated with luciferase reporter gene. Other GR mutants have decreased transcriptional activity, secondary to decreased GR nuclear translocation, DNA binding or transcriptional coregulatory recruitment.

accompanied by a decrease in hGR mRNA and/or hGR protein leading to a reduction of GR-regulated gene expression in white blood cells $(36)$ or fibroblasts $(37,38)$. Furthermore, by means of these investigations, it has been possible to explore some molecular mechanisms (nonsense mRNA decay, GR degradation, etc.), likely involved in GC insensitivity (37).

Recently, six new heterozygous missense mutations located within the NTD of the hGR have been incidentally discovered in a context of genetic screening of the NR3C1 gene by next-generation sequencing (NGS). They were predicted as pathogenic mutations by specific software. However, functional characterization of these amino acid substitutions demonstrated no impact on GR signaling (33). As a result, we believe that functional characterization is imperatively required to appropriately assess the deleterious or benign nature of newly discovered genetic alterations, so-called 'genetic incidentalomas' and to accurately predict their pathogenicity in patients.

\section{Clinical signs of GC insensitivity}

Given the wide diversity of GC actions, acting on multiple physiological processes (immunity, metabolism, adipocyte, proliferation, development, etc...), it is not surprising that altered GR signaling might affect several physiological functions that may lead to various clinical presentations in patients carrying GR loss-offunction mutations. We will briefly discuss some of them. In addition, contrary to the initial hypothesis based on physiological responses to mineralocorticoid agonist compounds, we have recently identified another molecular mechanism that may account for functional hypermineralocorticism demonstrated in these patients.

\section{Genotype-phenotype correlation}

As a whole, there is no clear genotype-phenotype relationship between the severity of the disease and the degree of mutant GRs' functional loss. Functional characterization of these mutations generally demonstrated a severely reduced GR transactivation capacity in five patients and a complete absence of transactivation in one patient. Ex vivo analysis revealed a marked GR haploinsufficiency even in some patients showing no clinical signs (38). Interestingly, the age at presentation does not seem to correlate with the severity of the impact on GR signaling as analyzed in vitro nor with the degree of GR haploinsufficiency evaluated ex vivo nor even with the homozygous nature of GR loss-offunction mutation. Younger patients in particular often presented with severe clinical signs, irrespective to the heterozygous or homozygous nature of the GR loss-offunction mutation.

\section{Milder phenotypes}

The most severe cases of patients with GR loss-of-function mutations were mainly reported in children, sometimes presenting with ambiguous genitalia at birth (39), resistant hypertension with small hemorrhagic cerebral 
infarcts (25) or severe sepsis associated with GH deficiency (35). A notable exception is the first discovered case, in a 48 year-old patient with high UFC level (>30 N) and high ACTH level $(>5 \mathrm{~N})$, associated with high blood pressure and hypokalemia (1). We recently described a set of much milder phenotypes of glucocorticoid-resistant patients (38) compared to the rather severe initial description (1). These former patients presented with moderately high UFC $(<5 \mathrm{~N})$ and often normal ACTH levels $(37,38,40)$, associated with variable clinical signs such as drug-controlled high blood pressure, hirsutism in women or adrenal hyperplasia. The existence of such milder phenotypes raises important questions about the molecular mechanisms initially proposed to explain clinical signs in these mutated GR patients.

\section{Adrenal hyperplasia}

Of the 33 mutated GR patients, adrenal hyperplasia was reported in 11 patients displaying bilateral and 2 unilateral adrenal hyperplasia. No adrenal hyperplasia was observed in three other patients. Recently, the French National Hospital Clinical Research Program (PHRC), called Muta-GR, was launched to evaluate the prevalence of NR3C1 mutations in a cohort of 100 patients presenting with bilateral adrenal hyperplasia (BAH), associated with high blood pressure and/or biological hypercortisolism without Cushing's syndrome signs (38). Five original heterozygous NR3C1 mutations were discovered in this group, leading to a 5\% prevalence of GR mutations, consistent with a new major genetic cause of BAH. The prevalence of a new tumor suppressor gene of Armadillo Repeat Containing Familly (ARMC5) is between 7.7 and $21 \%$ (39), inactivation of ARMC5 seems to be implicated in primary bilateral macronodular hyperplasia (41). The prevalence of genetic defects in other genes involved in BAH (GNAS mutations or PDE11A) is relatively low, described in one case out of 10 for GNAS mutations and 2 pathogenic PDE11A variants in a population of 46 patients with primary bilateral macronodular adrenal hyperplasia $(42,43)$. More recently, Vaczlavik et al. discovered 31 previously described GR variants, by NGS in a population of $389 \mathrm{BAH}$ and found a prevalence of $7.9 \%$ of NR3C1 variants (44) with one new GR variant, N454S, predicted to be a deleterious mutation that is currently being functionally characterized in our laboratory.

The involvement of altered GR signaling in adrenal hyperplasia could be at least partially explained by two molecular mechanisms. The first one is the cAMP pathway activation by ACTH overstimulation. Four heterozygous GR mutations were associated with $\mathrm{BAH}$, somehow related to high ACTH levels $(23,25,38,45)$. This was also demonstrated in the model of $n r 3 c 1$ gene inactivation in which homozygous GR knock out (KO) mice (3), had enlarged adrenal gland size and disorganized adrenocortical cells with high corticosterone and ACTH levels, consistent with HPA dysregulation (3). Mice died soon after birth. However, as mentioned earlier, the majority of patients harboring GR mutations had normal ACTH levels. Thus, the role of GR in adrenal hyperplasia remains unclear. A mouse model of GR haploinsufficiency in which only one GR allele was functional (46), also had enlarged adrenal glands (47) yet normal ACTH levels. This suggests that GR haploinsufficiency might be involved in the etiopathogeny of BAH. GR haploinsufficiency has also been recently demonstrated in fibroblasts of some patients carrying heterozygous GR loss-of-function mutations (38). The second mechanism consists of the autocrine positive regulatory loop exerted by GRs on steroidogenesis in human adrenocortical cell line (H295R), inhibited by GR antagonist RU486, which was also recently reported (48), while the involvement of GR was also evoked in the paradoxical increase in cortisol excretion in primary pigmented nodular adrenocortical disease (49). However, much work remains to be done to determine the exact contribution of GR function in the development of adrenal hyperplasia.

\section{High blood pressure}

Thirteen of the 33 GR-mutant patients had high blood pressure or were under anti-hypertensive therapy, while 15 had normal blood pressure. It was initially proposed that the high ACTH levels generally found in mutated GR patients may stimulate release of corticosteroids (corticosterone and 11-deoxycorticosterone) with mineralocorticoid agonist activities, i.e. that are, able to bind to and to activate the mineralocorticoid receptor (MR) (50), leading to sustained MR activation and subsequent sodium retention and volume expansion. However, as mentioned earlier, three patients among the 13 hypertensive mutated GR patients had normal ACTH levels, suggesting that other mechanisms may account for HBP in these cases. Patients included in the Muta-GR study presented with clinical, biological and hormonal signs, compatible with HBP and low renin levels but normal corticosterone and 11-deoxycorticosterone levels as measured by mass spectrometry. As illustrated in Fig. 3, the 11 $\beta$-HSD2, encoded by HSD11B2 gene, is mostly expressed in epithelial tissues (kidney, colon, 


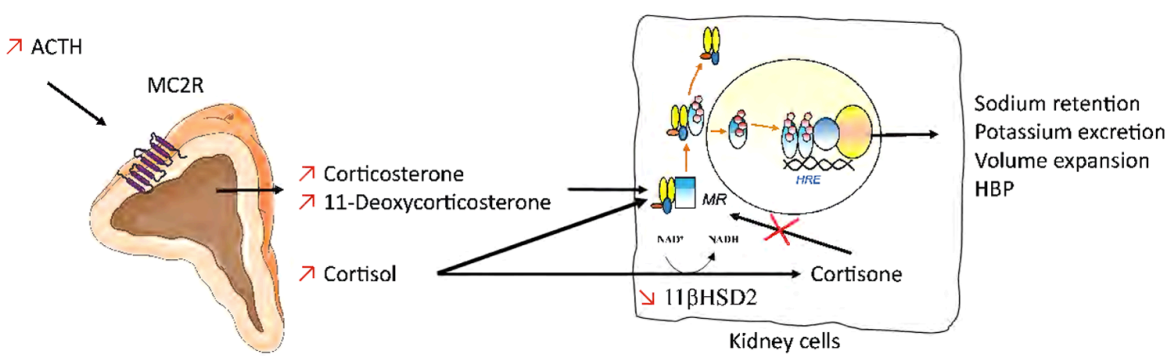

\section{Figure 3}

Proposed mechanisms involved in HBP associated with GR signaling defects. Some GR loss-of-function patients had high ACTH levels, leading to stimulation of corticosterone and 11 deoxycorticosterone release from adrenal glands, both steroid hormones that exert well-recognized mineralocorticoid agonist properties that is able to bind and activate MR. An alternative mechanism proposed for MR activation is the reduction of renal 11 $\beta \mathrm{HSD} 2$ activity. Alteration of GR signaling pathway in mutated GR patients induces decrease in HSD11B2 transcription and subsequently 11 $\beta$-HSD2 activity, allowing cortisol to bind and activate MR. MR activation is responsible for HBP due to sodium retention, volume expansion and finally high blood pressure. HBP, high blood pressure; MR, mineralocorticoid receptor.

placenta), and constitutes a MR-protecting mechanism (51) by catalyzing the interconversion of active cortisol (F) into inactive cortisone (E), which is unable to bind to the MR (52). Interestingly, a low 11ß-hydroxysteroid dehydrogenase type 2 (11 $\beta$-HSD2) activity was initially reported in one mutated GR patient (37) as revealed by low tetrahydrocortisone (THE)/tetrahydrocortisol (THF) ratio, indicative of an altered renal cortisol metabolism. Thus, the reduced renal 11 $\beta$-HSD2 activity could be responsible for illicit MR activation by cortisol excess. We have recently shown that HSD11B2 is a direct target gene of GR. We demonstrated that GR positively regulates human HSD11B2 promoter construct by co-transfection assays in HEK293T cells. We identified in silico seven half-degenerate GREs within the HSD11B2 regulatory sequences and showed a DXM-induced GR recruitment onto two specific half-GRE sites by ChIP (40). Given that GR haploinsufficiency is generally detected in mutated GR patients associated with a reduced induction of GR target genes, we hypothesized that lower renal 11 $\beta$-HSD2 activity may account for inappropriate MR activation by unmetabolized cortisol excess, as previously validated in one mutated GR patient (37). However, some mutated GR patients had no hypertension but among the 14 out of 15 patients with normal blood pressure, five patients displayed discrete and isolated renin-angiotensin-aldosterone system (RAAS) abnormalities, either low plasma renin levels or low plasma aldosterone concentrations, but with normal kalemia. Note that clinical and biological parameters were not available for 8 patients while one mutated GR patient had high aldosterone level. These subtle RAAS abnormalities may reflect the degree of the
HSD11B2 defect. Carvajal et al. previously described some patients carrying HSD11B2 heterozygous mutations who were normotensive with normal kalemia but with a high serum cortisol/cortisone ratio, reflecting a decrease

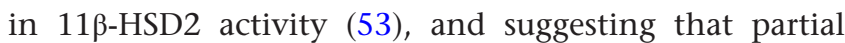
$11 \beta$-HSD2 deficiency may not always lead to overt arterial hypertension. Another study showed that mice with 11 $\beta$-HSD2 haploinsufficiency had a higher salt sensitivity of blood pressure (54), consistent with either a genetic susceptibility or a 'second hit' leading to a phenotype prone to develop hypertension or either a GR activation that could be excluded in GC-resistant patients owing to the deleterious consequences of GR loss-offunction mutations.

However, it is currently unknown if initially normotensive 11 $\beta$-HSD2-deficient patients are at higher risk of developing $\mathrm{HBP}$ and its related increased risk of cardiovascular events. Given that the $11 \beta$-HSD2 activity seems to decrease with aging and that patients could develop high blood pressure later on (55), we propose that mutated GR patients without high blood pressure should be carefully monitored since the long-term consequences of high blood pressure are well established.

\section{Hirsutism}

As reported in the literature, 13 out of 17 mutated GR women $(76 \%)$ had hirsutism. The severity of hirsutism is extremely variable, from mild-to-severe presentation (genital ambiguity at birth, virilization in newborn females). Among these 13 affected women, ACTH levels when tested, were in the normal range for four patients 
but high in six patients. In addition, 17-OH-progesterone (17OHP) concentrations were high for three of four patients, DHEA-S levels were high in two of six patients, plasma $\Delta 4$-androstenedione concentrations were high in three of four patients. Five of eight patients had high circulating testosterone levels, while three had normal testosterone concentrations. As a whole, all female patients had androgen abnormalities but the information is not available for four patients. Thus, hirsutism seems to be a relatively frequent event in mutated GR women, suggesting that genetic search for NR3C1 mutations should be performed more often in these patients especially those lacking other obvious causes such as enzymatic defects or tumor syndrome.

\section{Obesity}

Eight of 18 patients carrying GR loss-of-function mutations had elevated BMI $>25 \mathrm{~kg} / \mathrm{m}^{2}$. All of the eight mutated GR patients with high BMI also had elevated UFC. Two mechanisms may be involved in adipose tissue growth: hyperplasia (increase in cell number) or hypertrophia (increase in cell size) of adipocytes (56). The involvement of GC in adipose tissue development has already been demonstrated in Cushing's syndrome. Moreover, Constantinopoulos et al. previously highlighted the critical role of cortisol in the development of metabolic syndrome in severely obese patients (57), while Debono et al. found an increased visceral fat in patients with adrenal incidentalomas associated with a cortisol level greater than $50 \mathrm{nmol} / \mathrm{L}$ after dexamethasone suppression test (58), providing additional support for the contributing role of GC in the development of obesity. However, the molecular mechanisms underlying such an involvement in mutated GR patients remain to be further elucidated.

In adipose tissue, GC may bind and activate both GR and MR but the relative contribution of these two closely related transcription factors remains rather controversial. In obese patients, MR activation seems to be involved in inflammation and insulin resistance (59) and plays a major role in adipogenesis (60). In another study, Lee et al. demonstrated the importance of GR in promoting adipogenesis but not of the MR (61), while white-adiposetissue-specific GR-knockout mice displayed a healthier metabolic profile (62), except one report (63). GR blockade of adipogenesis seems to protect against the development of metabolic alterations. Thus, precise evaluation of metabolic profile of mutated GR patients should be established in order to carefully examine cardiovascular risk of these patients because the involvement of GR loss-of-function mutation did not seem to be directly responsible for obesity of these patients.

Collectively, the GC excess observed in mutated GR patients could be responsible for a visceral fat expansion and obesity, although fat localization was not precisely analyzed in these patients. Thus, precise monitoring of the metabolic profile of mutated GR patients should be established in order to carefully judge their cardiovascular risk.

\section{When to propose $N R 3 C 1$ sequencing?}

According to the Muta-GR study, a 5\% prevalence of NR3C1 mutations was found in a cohort of 100 patients with bilateral adrenal hyperplasia (38). We suppose that this prevalence is relatively high, suggesting that numerous GR loss-of function mutations may exist in the general population without obvious symptoms but may have unfortunately gone undetected. Indeed, another recent study has identified 2 heterozygous GR mutations among 12 patients with cortisol resistance syndrome (27). However, no GR mutations have been discovered among 51 hypertensive patients with low plasma renin activity and low serum aldosterone concentrations (64).

As a consequence, we proposed that NR3C1 genetic screening should be performed in selected patients, notably those presenting with bilateral adrenal hyperplasia associated with glucocorticoid resistance syndrome, kalemia $<4 \mathrm{mmol} / \mathrm{L}$ and plasma aldosterone levels below the lower limit of normal values. In such cases, approximately $50 \%$ of the patients may harbor GR loss-of-function mutation (38).

Such a clinical practice seems to be important since it should facilitate management of glucocorticoid-resistant patients, avoiding unnecessary adrenal surgery, proposing appropriate pharmacological strategies and careful longterm follow-up for the benefit of both the patients and their families.

\section{Conclusion}

GR loss-of-function mutations are rare genetic defects but they will be increasingly identified, notably in this era of next generation sequencing. The main clinical or biological signs at presentation could be high blood pressure, isolated renin-aldosterone abnormalities without HBP, hirsutism, or adrenal hyperplasia, associated in the majority of cases with glucocorticoid resistance syndrome. 
Familial investigations should be performed given the unpredictable evolution of the related pathologies, for the sake of the patients' and family members' interest in order to optimize their therapeutic management and avoid unnecessary surgery. We believe that a long-term follow-up of these patients is also required.

\section{Declaration of interest}

The authors declare that there is no conflict of interest that could be perceived as prejudicing the impartiality of this review.

\section{Funding}

$\mathrm{G} V$ is the recipient of a doctoral fellowship from the Fondation pour la Recherche Médicale (FRM). This work was supported by grants from Institut National de la Santé et de la Recherche Médicale (Inserm), and Paris-Sud University.

\section{Acknowledgments}

The authors would like to thank Prof. Brigitte Delemer (CHU Reims) who was co-principal investigator of the Muta-GR study. They thank Dr Jérôme Bouligand and Dr Severine Trabado (Inserm UMR_S1185 and Department of Molecular Genetics, Pharmacogenetics and Hormonology, CHU Bicêtre, France) for their implication in this project. GV is the recipient of a doctoral fellowship from the 'Fondation pour la Recherche Médicale' (FRM). They are also indebted to all clinical endocrinologists who refereed the patients' samples to our laboratory. They also would like to address a very special thanks to Dr R Karess, an American native English scientist (Institut Jacques Monod, Paris) for his careful English editing to the manuscript.

\section{References}

1 Vingerhoeds AC, Thijssen JH \& Schwarz F. Spontaneous hypercortisolism without Cushing's syndrome. Journal of Clinical Endocrinology and Metabolism 197643 1128-1133. (https://doi. org/10.1210/jcem-43-5-1128)

2 Hurley DM, Accili D, Stratakis CA, Karl M, Vamvakopoulos N, Rorer E, Constantine K, Taylor SI \& Chrousos GP. Point mutation causing a single amino acid substitution in the hormone binding domain of the glucocorticoid receptor in familial glucocorticoid resistance. Journal of Clinical Investigation 199187 680-686. (https:// doi.org/10.1172/JCI115046)

3 Cole TJ, Blendy JA, Monaghan AP, Krieglstein K, Schmid W, Aguzzi A, Fantuzzi G, Hummler E, Unsicker K \& Schütz G. Targeted disruption of the glucocorticoid receptor gene blocks adrenergic chromaffin cell development and severely retards lung maturation. Genes and Development 19959 1608-1621. (https://doi.org/10.1101/ gad.9.13.1608)

4 Rog-Zielinska EA, Thomson A, Kenyon CJ, Brownstein DG, Moran CM, Szumska D, Michailidou Z, Richardson J, Owen E, Watt A et al. Glucocorticoid receptor is required for foetal heart maturation. Human Molecular Genetics 201322 3269-3282. (https:// doi.org/10.1093/hmg/ddt182)

5 Gathercole LL, Lavery GG, Morgan SA, Cooper MS, Sinclair AJ, Tomlinson JW \& Stewart PM. 11 $\beta$-Hydroxysteroid dehydrogenase 1: translational and therapeutic aspects. Endocrine Reviews 201334 525-555. (https://doi.org/10.1210/er.2012-1050)

6 Cain DW \& Cidlowski JA. Immune regulation by glucocorticoids. Nature Reviews: Immunology 201717 233-247. (https://doi. org/10.1038/nri.2017.1)
7 Newell-Price J, Bertagna X, Grossman AB \& Nieman LK. Cushing's syndrome. Lancet 2006367 1605-1617. (https://doi.org/10.1016/ S0140-6736(06)68699-6)

8 Gomez MT, Magiakou MA, Mastorakos G \& Chrousos GP. The pituitary corticotroph is not the rate limiting step in the postoperative recovery of the hypothalamic-pituitary-adrenal axis in patients with Cushing syndrome. Journal of Clinical Endocrinology and Metabolism 199377 173-177. (https://doi.org/10.1210/ jcem.77.1.8392083)

9 Yudt MR \& Cidlowski JA. Molecular identification and characterization of a and $\mathrm{b}$ forms of the glucocorticoid receptor. Molecular Endocrinology 200115 1093-1103. (https://doi.org/10.1210/ mend.15.7.0667)

10 Lu NZ \& Cidlowski JA. Translational regulatory mechanisms generate $\mathrm{N}$-terminal glucocorticoid receptor isoforms with unique transcriptional target genes. Molecular Cell 200518 331-342. (https:// doi.org/10.1016/j.molcel.2005.03.025)

11 Nader N, Chrousos GP \& Kino T. Circadian rhythm transcription factor CLOCK regulates the transcriptional activity of the glucocorticoid receptor by acetylating its hinge region lysine cluster: potential physiological implications. FASEB Journal 200923 1572-1583. (https://doi.org/10.1096/fj.08-117697)

12 Cheung J \& Smith DF. Molecular chaperone interactions with steroid receptors: an update. Molecular Endocrinology 200014 939-946. (https://doi.org/10.1210/mend.14.7.0489)

13 Vitellius G, Trabado S, Bouligand J, Delemer B \& Lombès M. Pathophysiology of glucocorticoid signaling. Annales d'Endocrinologie 201879 98-106. (https://doi.org/10.1016/j.ando.2018.03.001)

14 Starick SR, Ibn-Salem J, Jurk M, Hernandez C, Love MI, Chung HR, Vingron M, Thomas-Chollier M \& Meijsing SH. ChIP-exo signal associated with DNA-binding motifs provides insight into the genomic binding of the glucocorticoid receptor and cooperating transcription factors. Genome Research 201525 825-835. (https://doi. org/10.1101/gr.185157.114)

15 Le Billan F, Amazit L, Bleakley K, Xue QY, Pussard E, Lhadj C, Kolkhof P, Viengchareun S, Fagart J \& Lombès M. Corticosteroid receptors adopt distinct cyclical transcriptional signatures. FASEB Journal 201832 5626-5639. (https://doi.org/10.1096/ fj.201800391RR)

16 Karin M. New twists in gene regulation by glucocorticoid receptor: is DNA binding dispensable? Cell 199893 487-490. (https://doi. org/10.1016/s0092-8674(00)81177-0)

17 Ayrout M, Simon V, Bernard V, Binart N, Cohen-Tannoudji J, Lombès $\mathrm{M} \&$ Chauvin $\mathrm{S}$. A novel non genomic glucocorticoid signaling mediated by a membrane palmitoylated glucocorticoid receptor cross talks with GnRH in gonadotrope cells. Scientific Reports 20177 1537. (https://doi.org/10.1038/s41598-017-01777-2)

18 Huizenga NA, de Lange P, Koper JW, de Herder WW, Abs R, Kasteren JH, de Jong FH \& Lamberts SW. Five patients with biochemical and/or clinical generalized glucocorticoid resistance without alterations in the glucocorticoid receptor gene. Journal of Clinical Endocrinology and Metabolism 200085 2076-2081. (https:// doi.org/10.1210/jcem.85.5.6542)

19 Russcher H, Smit P, van den Akker EL, van Rossum EFC, Brinkmann AO, de Jong FH, Lamberts SWJ \& Koper JW. Two polymorphisms in the glucocorticoid receptor gene directly affect glucocorticoid-regulated gene expression. Journal of Clinical Endocrinology and Metabolism 200590 5804-5810. (https://doi. org/10.1210/jc.2005-0646)

20 Schaaf MJM \& Cidlowski JA. AUUUA motifs in the 3'UTR of human glucocorticoid receptor alpha and beta mRNA destabilize mRNA and decrease receptor protein expression. Steroids 200267 627-636. (https://doi.org/10.1016/s0039-128x(02)00015-6)

21 van Rossum EFC, Koper JW, Huizenga NATM, Uitterlinden AG, Janssen JA, Brinkmann AO, Grobbee DE, de Jong FH, van Duyn CM, Pols HAP et al. A polymorphism in the glucocorticoid receptor gene, 
which decreases sensitivity to glucocorticoids in vivo, is associated with low insulin and cholesterol levels. Diabetes 200251 3128-3134. (https://doi.org/10.2337/diabetes.51.10.3128)

22 van den Akker ELT, Russcher H, van Rossum EFC, Brinkmann AO, de Jong FH, Hokken A, Pols HAP, Koper JW \& Lamberts SWJ. Glucocorticoid receptor polymorphism affects transrepression but not transactivation. Journal of Clinical Endocrinology and Metabolism 200691 2800-2803. (https://doi.org/10.1210/jc.2005-2119)

23 Al Argan R, Saskin A, Yang JW, D'Agostino MD \& Rivera J. Glucocorticoid resistance syndrome caused by a novel NR3C1 point mutation. Endocrine Journal 201865 1139-1146 . (https://doi. org/10.1507/endocri.EJ18-0135)

24 Molnár Á, Kövesdi A, Szücs N, Tóth M, Igaz P, Rácz K \& Patócs A. Polymorphisms of the GR and HSD11B1 genes influence body mass index and weight gain during hormone replacement treatment in patients with Addison's disease. Clinical Endocrinology 201685 180-188. (https://doi.org/10.1111/cen.13022)

25 Tatsi C, Xekouki P, Nioti O, Bachrach B, Belyavskaya E, Lyssikatos C $\&$ Stratakis CA. A novel mutation in the glucocorticoid receptor gene as a cause of severe glucocorticoid resistance complicated by hypertensive encephalopathy. Journal of Hypertension 201937 1475-1481. (https://doi.org/10.1097/HJH.0000000000002048)

26 Raef H, Baitei EY, Zou M \& Shi Y. Genotype-phenotype correlation in a family with primary cortisol resistance: possible modulating effect of the ER22/23EK polymorphism. European Journal of Endocrinology 2008158 577-582. (https://doi.org/10.1530/EJE-07-0629)

27 Ruiz M, Lind U, Gåfvels M, Eggertsen G, Carlstedt-Duke J, Nilsson L, Holtmann M, Stierna P, Wikström AC \& Werner S. Characterization of two novel mutations in the glucocorticoid receptor gene in patients with primary cortisol resistance. Clinical Endocrinology 2001 55 363-371. (https://doi.org/10.1046/j.1365-2265.2001.01323.x)

28 Nader N, Bachrach BE, Hurt DE, Gajula S, Pittman A, Lescher R $\&$ Kino T. A novel point mutation in helix 10 of the human glucocorticoid receptor causes generalized glucocorticoid resistance by disrupting the structure of the ligand-binding domain. Journal of Clinical Endocrinology and Metabolism 201095 2281-2285. (https:// doi.org/10.1210/jc.2009-2463)

29 Molnár Á, Patócs A, Likó I, Nyírő G, Rácz K, Tóth M \& Sármán B. An unexpected, mild phenotype of glucocorticoid resistance associated with glucocorticoid receptor gene mutation case report and review of the literature. BMC Medical Genetics 201819 37. (https://doi. org/10.1186/s12881-018-0552-6)

30 Fassnacht M, Arlt W, Bancos I, Dralle H, Newell-Price J, Sahdev A, Tabarin A, Terzolo M, Tsagarakis S \& Dekkers OM. Management of adrenal incidentalomas: European Society of Endocrinology Clinical Practice Guideline in collaboration with the European Network for the study of adrenal tumors. European Journal of Endocrinology 2016 175 G1-G34. (https://doi.org/10.1530/EJE-16-0467)

31 Nieman LK, Biller BMK, Findling JW, Newell-Price J, Savage MO, Stewart PM \& Montori VM. The diagnosis of Cushing's syndrome: an Endocrine Society Clinical Practice Guideline. Journal of Clinical Endocrinology and Metabolism 200893 1526-1540. (https://doi. org/10.1210/jc.2008-0125)

32 Vitellius G, Fagart J, Delemer B, Amazit L, Ramos N, Bouligand J, Le Billan F, Castinetti F, Guiochon-Mantel A, Trabado S et al. Three novel heterozygous point mutations of NR3C1 causing glucocorticoid resistance. Human Mutation 201637 794-803. (https://doi.org/10.1002/humu.23008)

33 Foussier L, Vitellius G, Bouligand J, Amazit L, Bouvattier C, Young J, Trabado $S$ \& Lombès $M$. Functional characterization of glucocorticoid receptor variants is required to avoid misinterpretation of NGS data. Journal of the Endocrine Society 20193 865-881. (https://doi. org/10.1210/js.2019-00028)

34 Charmandari E, Kino T, Ichijo T, Zachman K, Alatsatianos A \& Chrousos GP. Functional characterization of the natural human glucocorticoid receptor (hGR) mutants hGRalphaR477H and
hGRalphaG679S associated with generalized glucocorticoid resistance. Journal of Clinical Endocrinology and Metabolism 200691 1535-1543. (https://doi.org/10.1210/jc.2005-1893)

35 McMahon SK, Pretorius CJ, Ungerer JPJ, Salmon NJ, Conwell LS, Pearen MA \& Batch JA. Neonatal complete generalized glucocorticoid resistance and growth hormone deficiency caused by a novel homozygous mutation in Helix 12 of the ligand binding domain of the glucocorticoid receptor gene (NR3C1). Journal of Clinical Endocrinology and Metabolism 201095 297-302. (https://doi. org/10.1210/jc.2009-1003)

36 Russcher H, Smit P, van Rossum EFC, van den Akker ELT, Brinkmann AO, de Heide LJM, de Jong FH, Koper JW \& Lamberts SWJ. Strategies for the characterization of disorders in cortisol sensitivity. Journal of Clinical Endocrinology and Metabolism 200691 694-701. (https://doi.org/10.1210/jc.2005-2212)

37 Bouligand J, Delemer B, Hecart AC, Meduri G, Viengchareun S, Amazit L, Trabado S, Fève B, Guiochon-Mantel A, Young J et al. Familial glucocorticoid receptor haploinsufficiency by nonsense mediated mRNA decay, adrenal hyperplasia and apparent mineralocorticoid excess. PLoS ONE 20105 e13563. (https://doi. org/10.1371/journal.pone.0013563)

38 Vitellius G, Trabado S, Hoeffel C, Bouligand J, Bennet A, Castinetti F, Decoudier B, Guiochon-Mantel A, Lombes M, Delemer B et al. Significant prevalence of NR3C1 mutations in incidentally discovered bilateral adrenal hyperplasia: results of the French Muta-GR Study. European Journal of Endocrinology 2018178 411-423. (https://doi.org/10.1530/EJE-17-1071)

39 Mendonca BB, Leite MV, de Castro M, Kino T, Elias LLK, Bachega TAS, Arnhold IJP, Chrousos GP \& Latronico AC. Female pseudohermaphroditism caused by a novel homozygous missense mutation of the GR gene. Journal of Clinical Endocrinology and Metabolism 200287 1805-1809. (https://doi.org/10.1210/ jcem.87.4.8379)

40 Vitellius G, Delemer B, Caron P, Chabre O, Bouligand J, Pussard E, Trabado $S \&$ Lombès $M$. Impaired $11 \beta$-hydroxysteroid dehydrogenase type 2 in glucocorticoid resistant patients. Journal of Clinical Endocrinology and Metabolism 2019104 5205-5216. (https://doi. org/10.1210/jc.2019-00800)

41 Assié G, Libé R, Espiard S, Rizk-Rabin M, Guimier A, Luscap W, Barreau O, Lefèvre L, Sibony M, Guignat L et al. ARMC5 mutations in macronodular adrenal hyperplasia with Cushing's syndrome. New England Journal of Medicine 2013369 2105-2114. (https://doi. org/10.1056/NEJMoa1304603)

42 Libé R \& Bertherat J. Molecular genetics of adrenocortical tumours, from familial to sporadic diseases. European Journal of Endocrinology 2005153 477-487. (https://doi.org/10.1530/eje.1.02004)

43 Vezzosi D, Libé R, Baudry C, Rizk-Rabin M, Horvath A, Levy I, René-Corail F, Ragazzon B, Stratakis CA, Vandecasteele G et al. Phosphodiesterase 11A (PDE11A) gene defects in patients with acthindependent macronodular adrenal hyperplasia (AIMAH): functional variants may contribute to genetic susceptibility of bilateral adrenal tumors. Journal of Clinical Endocrinology and Metabolism 201297 E2063-E2069. (https://doi.org/10.1210/jc.2012-2275)

44 Vaczlavik A, Vaduva P, Bouys L, Néou M, Septier A, Heurtier V, Libé R, Kroiss M, Borson-Chazot F, Chanson P et al. Genetic predisposition to primary bilateral macronodular adrenal hyperplasia (PBMAH): next generation sequencing ARMC5, NR3C1 (glucocorticoid receptor) and PDE11A4 (phosphodiesterase 11) in 389 patients. 21st European Congress of Endocrinology, Lyon. Endocrine Abstracts 2019 63 OC10.3. (https://doi.org/10.1530/endoabs.63.OC10.3)

45 Charmandari E, Kino T, Ichijo T, Jubiz W, Mejia L, Zachman K \& Chrousos GP. A novel point mutation in helix 11 of the ligandbinding domain of the human glucocorticoid receptor gene causing generalized glucocorticoid resistance. Journal of Clinical Endocrinology and Metabolism 200792 3986-3990. (https://doi.org/10.1210/ jc.2006-2830) 
46 Albiger NM, Regazzo D, Rubin B, Ferrara AM, Rizzati S, Taschin E, Ceccato F, Arnaldi G, Pecori Giraldi F, Stigliano A et al. A multicenter experience on the prevalence of ARMC5 mutations in patients with primary bilateral macronodular adrenal hyperplasia: from genetic characterization to clinical phenotype. Endocrine 201755 959-968. (https://doi.org/10.1007/s12020-016-0956-z)

47 Michailidou Z, Carter RN, Marshall E, Sutherland HG, Brownstein DG, Owen E, Cockett K, Kelly V, Ramage L, Al-Dujaili EA et al. Glucocorticoid receptor haploinsufficiency causes hypertension and attenuates hypothalamic-pituitary-adrenal axis and blood pressure adaptions to high-fat diet. FASEB Journal 200822 3896-3907. (https://doi.org/10.1096/fj.08-111914)

48 Asser L, Hescot S, Viengchareun S, Delemer B, Trabado S \& Lombès M. Autocrine positive regulatory feedback of glucocorticoid secretion: glucocorticoid receptor directly impacts H295R human adrenocortical cell function. Molecular and Cellular Endocrinology 2014 395 1-9. (https://doi.org/10.1016/j.mce.2014.07.012)

49 Bourdeau I, Lacroix A, Schürch W, Caron P, Antakly T \& Stratakis CA. Primary pigmented nodular adrenocortical disease: paradoxical responses of cortisol secretion to dexamethasone occur in vitro and are associated with increased expression of the glucocorticoid receptor. Journal of Clinical Endocrinology and Metabolism $2003 \mathbf{8 8}$ 3931-3937. (https://doi.org/10.1210/jc.2002-022001)

50 Bertagna X. Effects of chronic ACTH excess on human adrenal cortex. Frontiers in Endocrinology 2017843 . (https://doi.org/10.3389/ fendo.2017.00043)

51 Edwards CR, Stewart PM, Burt D, Brett L, McIntyre MA, Sutanto WS, de Kloet ER \& Monder C. Localisation of 11 beta-hydroxysteroid dehydrogenase - tissue specific protector of the mineralocorticoid receptor. Lancet 19882 986-989. (https://doi.org/10.1016/s01406736(88)90742-8)

52 White PC. Alterations of cortisol metabolism in human disorders. Hormone Research in Paediatrics 201889 320-330. (https://doi. org/10.1159/000485508)

53 Carvajal CA, Tapia-Castillo A, Valdivia CP, Allende F, Solari S, Lagos CF, Campino C, Martínez-Aguayo A, Vecchiola A, Pinochet C et al. Serum cortisol and cortisone as potential biomarkers of partial $11 \beta$-hydroxysteroid dehydrogenase type 2 deficiency. American Journal of Hypertension 201831 910-918. (https://doi.org/10.1093/ ajh/hpy051)

54 Bailey MA, Craigie E, Livingstone DEW, Kotelevtsev YV, Al-Dujaili EAS, Kenyon CJ \& Mullins JJ. Hsd11b2 haploinsufficiency in mice causes salt sensitivity of blood pressure. Hypertension 201157 515-520. (https://doi.org/10.1161/HYPERTENSIONAHA.110.163782)

55 Henschkowski J, Stuck AE, Frey BM, Gillmann G, Dick B, Frey FJ \& Mohaupt MG. Age-dependent decrease in 11beta-hydroxysteroid dehydrogenase type 2 (11beta-HSD2) activity in hypertensive patients. American Journal of Hypertension 200821 644-649. (https:// doi.org/10.1038/ajh.2008.152)

56 Jo J, Gavrilova O, Pack S, Jou W, Mullen S, Sumner AE, Cushman SW \& Periwal V. Hypertrophy and/or hyperplasia: dynamics of adipose tissue growth. PLoS Computational Biology 20095 e1000324. (https:// doi.org/10.1371/journal.pcbi.1000324)

57 Constantinopoulos P, Michalaki M, Kottorou A, Habeos I, Psyrogiannis A, Kalfarentzos F \& Kyriazopoulou V. Cortisol in tissue and systemic level as a contributing factor to the development of metabolic syndrome in severely obese patients. European Journal of Endocrinology 2015172 69-78. (https://doi.org/10.1530/EJE-14-0626)

58 Debono M, Prema A, Hughes TJB, Bull M, Ross RJ \& Newell-Price J. Visceral fat accumulation and postdexamethasone serum cortisol levels in patients with adrenal incidentaloma. Journal of Clinical Endocrinology and Metabolism 201398 2383-2391. (https://doi. org/10.1210/jc.2012-4276)

59 Hirata A, Maeda N, Hiuge A, Hibuse T, Fujita K, Okada T, Kihara S, Funahashi T \& Shimomura I. Blockade of mineralocorticoid receptor reverses adipocyte dysfunction and insulin resistance in obese mice.
Cardiovascular Research 200984 164-172. (https://doi.org/10.1093/ cvr/cvp191)

60 Caprio M, Antelmi A, Chetrite G, Muscat A, Mammi C, Marzolla V, Fabbri A, Zennaro MC \& Fève B. Antiadipogenic effects of the mineralocorticoid receptor antagonist drospirenone: potential implications for the treatment of metabolic syndrome. Endocrinology 2011152 113-125. (https://doi.org/10.1210/en.2010-0674)

61 Lee MJ \& Fried SK. The glucocorticoid receptor, not the mineralocorticoid receptor, plays the dominant role in adipogenesis and adipokine production in human adipocytes. International Journal of Obesity 201438 1228-1233. (https://doi.org/10.1038/ijo.2014.6)

62 Dalle H, Garcia M, Antoine B, Boehm V, Do TTH, Buyse M, Ledent T, Lamazière A, Magnan C, Postic C et al. Adipocyte glucocorticoid receptor deficiency promotes adipose tissue expandability and improves the metabolic profile under corticosterone exposure. Diabetes 201968 305-317. (https://doi.org/10.2337/db17-1577)

63 Desarzens S \& Faresse N. Adipocyte glucocorticoid receptor has a minor contribution in adipose tissue growth. Journal of Endocrinology 2016230 1-11. (https://doi.org/10.1530/JOE-16-0121)

64 Donner KM, Hiltunen TP, Jänne OA, Sane T \& Kontula K. Generalized glucocorticoid resistance caused by a novel twonucleotide deletion in the hormone-binding domain of the glucocorticoid receptor gene NR3C1. European Journal of Endocrinology 2013168 K9-K18. (https://doi.org/10.1530/EJE-12-0532)

65 Roberts ML, Kino T, Nicolaides NC, Hurt DE, Katsantoni E, Sertedaki A, Komianou F, Kassiou K, Chrousos GP \& Charmandari E. A novel point mutation in the DNA-binding domain (DBD) of the human glucocorticoid receptor causes primary generalized glucocorticoid resistance by disrupting the hydrophobic structure of its DBD. Journal of Clinical Endocrinology and Metabolism 201398 E790-E795. (https://doi.org/10.1210/jc.2012-3549)

66 Zhu HJ, Dai YF, Wang O, Li M, Lu L, Zhao WG, Xing XP, Pan H, Li NS $\&$ Gong FY. Generalized glucocorticoid resistance accompanied with an adrenocortical adenoma and caused by a novel point mutation of human glucocorticoid receptor gene. Chinese Medical Journal 2011 124 551-555.

67 Karl M, Lamberts SW, Koper JW, Katz DA, Huizenga NE, Kino T, Haddad BR, Hughes MR \& Chrousos GP. Cushing's disease preceded by generalized glucocorticoid resistance: clinical consequences of a novel, dominant-negative glucocorticoid receptor mutation. Proceedings of the Association of American Physicians 1996108 296-307.

68 Nicolaides NC, Roberts ML, Kino T, Braatvedt G, Hurt DE, Katsantoni E, Sertedaki A, Chrousos GP \& Charmandari E. A novel point mutation of the human glucocorticoid receptor gene causes primary generalized glucocorticoid resistance through impaired interaction with the LXXLL motif of the p160 coactivators: dissociation of the transactivating and transreppressive activities. Journal of Clinical Endocrinology and Metabolism 201499 E902-E907. (https://doi.org/10.1210/jc.2013-3005)

69 Velayos T, Grau G, Rica I, Pérez-Nanclares G \& Gaztambide S. Glucocorticoid resistance syndrome caused by two novel mutations in the NR3C1 gene. Endocrinologia y Nutricion 201663 369-371. (https://doi.org/10.1016/j.endonu.2016.03.010)

70 Cannavò S, Benvenga S, Messina E, Moleti M \& Ferraù F. Comment to 'glucocorticoid resistance syndrome caused by a novel NR3C1 point mutation' by Al Argan et al. Endocrine Journal 201966657. (https://doi.org/10.1507/endocrj.EJ19-0122)

71 Trebble P, Matthews L, Blaikley J, Wayte AWO, Black GCM, Wilton A $\&$ Ray DW. Familial glucocorticoid resistance caused by a novel frameshift glucocorticoid receptor mutation. Journal of Clinical Endocrinology and Metabolism 201095 E490-E499. (https://doi. org/10.1210/jc.2010-0705)

72 Karl M, Lamberts SW, Detera-Wadleigh SD, Encio IJ, Stratakis CA, Hurley DM, Accili D \& Chrousos GP. Familial glucocorticoid resistance caused by a splice site deletion in the human glucocorticoid receptor gene. Journal of Clinical Endocrinology 
and Metabolism 199376 683-689. (https://doi.org/10.1210/ jcem.76.3.8445027)

73 Chrousos GP, Vingerhoeds A, Brandon D, Eil C, Pugeat M, DeVroede M, Loriaux DL \& Lipsett MB. Primary cortisol resistance in man. A glucocorticoid receptor-mediated disease. Journal of Clinical Investigation 198269 1261-1269. (https://doi.org/10.1172/jci110565)

74 Nicolaides NC, Geer EB, Vlachakis D, Roberts ML, Psarra AMG, Moutsatsou P, Sertedaki A, Kossida S \& Charmandari E. A novel mutation of the hGR gene causing Chrousos syndrome. European Journal of Clinical Investigation $2015 \mathbf{4 5}$ 782-791. (https://doi. org/10.1111/eci.12470)

75 Charmandari E, Kino T, Souvatzoglou E, Vottero A, Bhattacharyya N \& Chrousos GP. Natural glucocorticoid receptor mutants causing generalized glucocorticoid resistance: molecular genotype, genetic transmission, and clinical phenotype. Journal of Clinical Endocrinology and Metabolism 200489 1939-1949. (https://doi.org/10.1210/ jc.2003-030450)

76 Vottero A, Kino T, Combe H, Lecomte P \& Chrousos GP. A novel, C-terminal dominant negative mutation of the GR causes familial glucocorticoid resistance through abnormal interactions with p160 steroid receptor coactivators. Journal of Clinical Endocrinology and Metabolism 200287 2658-2667. (https://doi.org/10.1210/ jcem.87.6.8520)

77 Charmandari E, Raji A, Kino T, Ichijo T, Tiulpakov A, Zachman K $\&$ Chrousos GP. A novel point mutation in the ligand-binding domain (LBD) of the human glucocorticoid receptor (hGR) causing generalized glucocorticoid resistance: the importance of the C terminus of hGR LBD in conferring transactivational activity. Journal of Clinical Endocrinology and Metabolism 200590 3696-3705. (https:// doi.org/10.1210/jc.2004-1920)

Received 11 October 2019

Revised version received 13 November 2019

Accepted 25 November 2019 